\title{
GOAL SETTING THEORY: THE EFFECT OF INCENTIVE MODERATION ON INDIVIDUAL PERFORMANCE
}

\author{
Yudi Hartono ${ }^{1}$ \\ Monika Palupi Murniati ${ }^{2}$ \\ Economics and Business Faculty \\ Soegijapranata Catholic University Semarang-Indonesia \\ palupi@unika.ac.id \\ Corresponding Author: Monika Palupi
}

\author{
A R T I C L E I N F O \\ Article history: \\ Received : 9 Nov 2020 \\ Revised : 13 Nov 2020 \\ Accepted : 20 Nov 2020
}

Key words:

Goal specifity, goal difficulty, incentive system

DOI: https://doi.org/10.33508/rima.v3i2.3053

\begin{abstract}
A B S T R A C T
This study uses goal-setting theory and reinforcement theory to explain the formation of individual motivation in achieving goals. Testing the effect of goal specificity used the experimental method to test the impact of goal specificity, different goal difficulty on the same quota incentive system as the $2 \times 2 \times 1$ experimental design. This study's findings confirm the goalsetting theory shown from the higher achievement of participants' goals when participants are given specific and challenging goals than participant goals in different variations of goal specificity and goal difficulty. This study found that participants have a greater focus on goal specificity in driving goal attainment behavior. The findings of this study confirm the reinforcement theory shown from achieving goals that exceed targets. Positive consequences become arguments for individuals to do the same action.
\end{abstract}

\section{INTRODUCTION}

Locke's goal-setting theory has been used in many studies to explain individual motivation to achieve unique performance (Locke, 1968). Two dimensions of the content attribute in the goal-setting view, specificity, and difficulty explain that goal-setting distinguishes individual performance achievement from one another. Specificity refers to the level of clarity of goals that appear quantitatively or provide a clear definition of the goals that must be achieved (Klein et al., 1990 and Swezey et al., 1994. Meanwhile, the difficulty dimension explains the difficulty level of objectives that must be completed by individuals. And goal difficulty moves the individual's internal motivation by understanding what is expected of his superior or the organization. Consequently, individuals will try to achieve the goals that have been set by managing abilities and planning well for each activity to achieve goals.

Several previous studies have found inconclusive results regarding goal specificity and goal difficulty on individual performance achievement. Locke et al. (1989), Latham et al. (2004), Arsanti (2009) found that goal specificity and goal difficulty did not affect performance achievement. In contrast, Latham and Yulk (1975), Klein and Daniel (1990), Wallace and Etkin (2017), Cheng et al. 2017 found that goal specificity and goal difficulty affect performance achievement. The second attribute of goal setting theory, intensity, can be used to explain inconclusive research results. Latham and Locke (1991) state that power generally is scope, clarity (clarity), and mental effort. Gollwitzer et al. (1990) explained this intensity attribute by 
finding that subjects who think most intensely and comprehensively in solving problems will have a significant commitment to finding solutions to the issues at hand. Attachment and the importance of achieving goals become arguments for the formation of goal attainment behavior by individuals.

The incentive system in the process of achieving goals has a vital role in driving individual instrumental motivation. The incentive quota system is an incentive system that provides rewards when individuals can exceed the set targets. Latham and Locke (1991) explain that compensation will affect individual performance achievement. Still, the premium effect will be useful when individuals have a good understanding of goals, goal specificity, and goal difficulty. This means that the incentive system has a role as a moderating variable to explain the effects of goal specificity and goal difficulty on performance achievement.

Reinforcement theory explains the role of incentive systems as positive reinforcers that shape individual behavior. This theory uses a behavioral approach to explain the part of the incentive system in shaping individual behavior. Consequences that provide benefits or positive effects for individuals make individuals repeat the action. When the goal is achieved, the individual gets positive implications in the form of rewards.

This research is motivated by a theoretical perspective. This study uses two theories with different approaches, namely a cognitive approach and a behavioral approach, to explain individual motivation to achieve goals. Both systems provide an understanding that behavior is influenced by antecedent and consequent treatment received by individuals.

\section{LITERATURE REVIEW AND HYPOTHESIS DEVELOPMENT}

Goal-Setting Theory

The theory put forward by Locke explains the relationship between goals and performance (Latham and Yukl, 1975). A goal-setting approach explains why individuals have different performance achievements when they have the same abilities and knowledge. Goal setting that individuals realize and understand becomes the motivation that drives individual behavior to achieve goals. Cognitive processes play a role in individuals when goals are set so that dreams become determinants of personal conduct.

Goal-setting theory has two attributes to explain individual behavior in achieving goals: content and intensity (Latham and Locke, 1991). The content attribute is related to the characteristics of the objectives described by goal specificity and goal difficulty. Goal specificity describes how specific or clear a goal is defined so that goal could adequately understand. Typical goal setting can refer to the quantitative characteristics of dreams. The purposes stated quantitatively are more comfortable for individuals to understand so that individual cognitive processes will occur to think about what to do to achieve these goals. Some research supports the explanation that goal specificity affects the achievement of goals (Kleingled and Heleen, 2011; Wallace et al., 2017), psychological empowerment (Jong and Sue, 2020).

Latham and Locke (1991) explain goal difficulty as ease of achieving goals, namely easy, medium, and impossible to achieve. The relationship between goal difficulty and performance is described by Atinkson in the form of an inverted $U$, meaning that more difficult goals will increase performance. Still, to a certain point, the difficulty of goals will decrease individual performance. At this stage, the intensity attribute explains how achieving goals requires the personal intensity to think about what to do. Commitment is the central aspect that shows intensity goals. Participation, incentive systems, self-efficacy, feedback are aspects that can shape individual responsibility in the process of achieving goals.

The two attributes of the goal-setting theory above provide a comprehensive 
understanding of the individual motivation to achieve specific goals. The cognitive approach is the way this theory explains how individuals are motivated by goal setting to form certain behaviors. The characteristics of the objectives and the scope that affect individual efforts to achieve goals are important factors that move individuals internally and externally to behave in a certain way.

\section{Reinforcement Theory}

Reinforcement theory has a different approach from goal-setting ideas in explaining individual goal-achieving behavior. Skinner (1953) demonstrated that individual behavior is shaped by the consequences that will be received when individuals achieve specific goals. Reinforcement theory has two forms to explain individual behavior, namely:

(1) positive reinforcement, and this form explains that individuals have the motivation to achieve goals because of positive consequences that will be received, for example, rewards, awards, promotions, and others.

(2) Negative reinforcement, in contrast to positive reinforcement, explains the formation of individual motivation to achieve goals for negative consequences that will be received when dreams are not fulfilled.

Feedback is a reinforcer factor. Individuals will learn to respond to feedback from the consequences received from specific behavior. Newstrom and Davis (1993) explain that individuals tend to have the same action when the behavior results provide benefits for themselves and vice versa. The feedback factor in this theory becomes the driving force for the growth of individual motivation to behave in achieving goals.

\section{Hypothesis Development}

Goal specificity shows how the goals are set (specific) so that individuals can understand what kind of goals will be achieved. A quantitative statement of goals helps individuals to understand quantitatively what is expected and must be completed. Goal difficulty shows the difficulty level of a plan to be achieved. The story of hardship acts as a challenge and becomes the motivation for individuals to achieve goals. These two factors are essential characteristics in the goal-setting process. Goals that are clearly stated and have challenges influence the individual's cognitive processes for planning and how to achieve those goals.

Locke and Latham (1990) stated that challenging goals would be a challenge for individuals to achieve them when they are clearly defined. Klein and Daniel (1990), Arsanti (2009), Murniati et al. (2016), Wallace and Etkin (2017), and Justin et al. 2017 found that the level of difficulty and clarity of goals affect individual performance. Individuals who have clear goals with a high level of difficulty will encourage individuals to plan, identify what is needed and determine strategies to achieve these goals. The main principle of goal setting by Locke (1968) states that setting challenging targets will improve performance compared to setting easy targets. The same thing with specificity. specific (precise) target setting is more effective than personal target setting or even no target. This statement is supported by the study of Early et al. (1990), which found that performance will increase when setting challenging and specific targets.

Reinforcement theory emphasizes the incentive system's role as a form of feedback from achieving goals, which in the goalsetting theory is explained by the intensity attribute. Incentive systems provide information about the consequences that will be received by individuals when goals are achieved. The incentives that will be accepted are feedback that delivers a positive experience for individuals so that individuals tend to do the same thing. The interaction between setting clear and challenging goals with an incentive system will affect individual performance achievement. Individuals with a level of clarity and difficulty with goals with specific incentive 
systems will affect their cognitive processes in achieving goals. This means that at different levels of goal setting, individuals will have other performance.

H1: There are differences in individual performance when the target is perceived as complicated and specific by the subject and when the target is perceived as easy and nonspecific by the subject which is given incentives with the quota scheme

$\mathrm{H} 2$ : There is a difference in individual performance when the target is perceived as difficult and non-specific by the subject and when the target is perceived as easy and specific by residents who are given incentives with a quota scheme

\section{RESEARCH METHOD}

Experimental Design and Methods

This study used an experimental method. Through the experimental protocol, the researcher gave the treatment of goal specificity, goal difficulty, a quota-based incentive system, and observed changes in the dependent variable, namely individual performance. The experimental design of this research is $2 \times 2 \times 1$, as in table 1 below:

Table 1: Experiment Design

\begin{tabular}{|c|c|c|c|}
\hline \multirow{2}{*}{$\begin{array}{c}\text { Goal } \\
\text { Difficulty }\end{array}$} & \multicolumn{2}{|c|}{ Goal Specificity } & \multirow{2}{*}{$\begin{array}{l}\text { Incentive } \\
\text { System }\end{array}$} \\
\hline & $\begin{array}{c}\text { Spesific } \\
\text { Target }\end{array}$ & $\begin{array}{c}\text { Non-spesific } \\
\text { target }\end{array}$ & \\
\hline Hard Target & 1 & 3 & Quota \\
\hline EasyTarget & 4 & 2 & \\
\hline
\end{tabular}

Participants were randomly assigned to four cells with treatment; participants received targets that had a variety of goalsetting theory attributes, namely specific and non-specific targets, as well as challenging and easy targets. Meanwhile, the treatment of the incentive system was the same for each cell. The experimental protocol pilot was carried out to test the treatments to be given to participants and get responses from the pilot participants. Participant responses are used to improve the experimental protocol to produce the right treatment at the experiment time. The experimental protocol is presented in a software form and carried out in a computer laboratory available. Participants can randomly select computers that already contain available treatments.

\section{Participants}

Participants in this study were students at the Faculty of Economics and Business, Soegijapranata Unika. Students have a role as employees who get coding tasks, namely changing numbers into letters. Considering the types of functions that do not require particular skills, it is argued that the participants involved in the research do not have individual requirements.

\section{Variable Measurement and Analysis Tools} Individual performance variables are measured by the number of correct coding that can be achieved by participants. The goal difficulty variable is an independent variable that gets two treatments: the target number of accurate coding that is difficult to achieve and the number of proper coding that is easy to achieve. The average number of correct encodings performed at the time of the pilot protocol became the basis for determining the target difficulty level for the number of valid codings. Easily achievable targets are set equal to average, and hard-to-achieve targets are set above average. The number of increasing coding targets informed to participants was a treatment for the goal specificity variable.

Meanwhile, the quota incentive system provides an incentive system by giving targets to participants and giving additional bonuses based on the excess 
number of correct coding of the given target. The variable goal difficulty goal specificity and the quota incentive system are variables that are only given treatment without being measured. Manipulation checks are carried out to ensure that participants understand the information and tasks provided in the experimental protocol. Testing the hypothesis in this study using the independent sample ttest

\section{Research paradigm}

This research uses a quantitative approach with an experimental method. Researchers provide treatment or commitment to variable goal specificity, goal difficulty, and an incentive system to participants. Participant responses become data that will be processed with statistical tools to test hypotheses that have been formulated based on theory and logic.

\section{RESULTS AND DISCUSSION}

Participants involved in this study were 60 students, 11 of whom did not pass the manipulation check for the treatment given, so they were not included in the data processing. This study uses gender, age, and origin of the study program as participant characteristics. The participant homogeneity test is shown in table 2 below:

Table 2: Test of differences in performance between cells based on participant characteristics

\begin{tabular}{|c|c|}
\hline Characteristics & Sig 5\% \\
\hline Gender & 0,260 \\
\hline Age & 0,336 \\
\hline Origin of the study program & 0,661 \\
\hline
\end{tabular}

Source : Attachment 2

The significance value $>5 \%$ states that there is no difference in the participants' performance in each cell based on gender, age, and origin of the study program. This means that there is no effect of participant characteristics on performance achievement. In other words, performance achievement is only affected by the treatment of the independent variable. The randomization process is carried out to remove obstacles to the internal validity of the experimental protocol.

Table 3: Different Test Hypothesis 1

\begin{tabular}{|c|c|c|}
\hline Information & Mean Difference & Sig. \\
\hline $\begin{array}{c}\text { Performance_Complicated } \\
\text { and specific goals_Quota }\end{array}$ & 170,36 & 0,039 \\
\cline { 1 - 2 } $\begin{array}{c}\text { Performance_Easy and } \\
\text { non-specific goal_Quota }\end{array}$ & 139,73 & \\
Source : Attachment 3
\end{tabular}

The results of hypothesis testing in table 3 show a significant difference in the average performance achievement of participants who have complicated and specific goals and participants who have easy and non-specific plans, which is indicated by the sig value of

\section{Hypothesis Findings 1}

This study's first hypothesis examines differences in individual performance when the target is perceived as complicated and specific by participants. The target is perceived as easy and non-specific by participants who are given incentives with a quota scheme. The results of testing the first hypothesis are shown in table 3 below:
0.039 smaller than a $5 \%$. Participants' average performance with challenging and specific goals has a higher performance than the average performance of participants with easy and non-specific goals in the same incentive system. 
The above test results confirm the goal-setting theory that participants with challenging and specific goals have a more excellent performance than participants with easy and non-specific goals. The difference in the average commission is significantly different. These findings prove that setting challenging and specific goals can shape individual motivation to achieve high performance. The cognitive approach used by goal-setting theory explains that participants who are given challenging goals and clear (specific) goals will try to make plans and strategies and think about what is needed to achieve them.
Hypothesis Findings 2

The second hypothesis in this study is that there is a difference in individual performance when the target is perceived as difficult and non-specific by the subject. The target is perceived as easy and specific by residents who are given incentives with a quota scheme. This second hypothesis tests the positive effect of goal specificity and goal difficulty at different and separate levels. This can be seen from the cells with participants given specific goals but easy to achieve and not exhaustive but challenging to achieve. The results of testing the second hypothesis are shown in table 4 below:

Table 4: Different Test Hypotheses 2

\begin{tabular}{|l|c|c|}
\hline \multicolumn{1}{|c|}{ Information } & Mean Difference & Sig. \\
\hline $\begin{array}{l}\text { Kinerja_Complicated and } \\
\text { non-specific goals_Quota }\end{array}$ & 145,92 & 0,648 \\
\cline { 1 - 1 } $\begin{array}{l}\text { Kinerja_Easy and specific } \\
\text { goals_Quota }\end{array}$ & 151,93 & \\
\hline
\end{tabular}

\section{Source: Attachment 3}

The results of testing the second hypothesis indicate that participants who are given challenging and non-specific goals have a performance that is not significantly different from those given easy and specific goals. This is characterized by a significance level greater than 5\%. This means that the second hypothesis in this study is not accepted.

Participants' mean performance from the two cells above shows that participants with easy and specific goals have a more excellent account than participants with challenging and non-specific goals. Although the difference in performance magnitude is not significant, descriptively, this difference in performance suggests that participants prefer setting specific goals (goal specificity) compared to challenging goals (goal difficulty). This is indicated by the performance score of the participants. Although the goals set are easy but specific have a more excellent performance than when the goals are set complicated and not typical.
The goal-setting theory explains that specific goals make individuals clearly understand the goals that must be achieved. Knowledge of the plans will encourage individuals to make various efforts necessary to achieve them. This study indicates that the level of goal difficulty, which acts as a challenge for individuals, cannot be as good as when individuals accept specific goals.

\section{Incentive System and Sensitivity Analysis}

This study uses a quota incentive system for all cells in the experimental design. At the end of the experiment, participants were asked questions about what the participants focused on when doing the coding task. This testing protocol provides two options: the correct coding target and the number of vouchers obtained. This question is presented to measure the participants' intention when doing the coding task. From the two coding sessions, participants can learn from the consequences received from the coding scheme's achievement so that in 
this treatment, the concepts of goal setting theory and reinforcement theory can be applied.

The results of the performance and arguments of the participants when carrying

Table 5: Participant Performance and Preference for Coding Arguments

\begin{tabular}{|l|l|l|}
\hline $\begin{array}{l}\text { Target Condition } \\
(\text { Goal })\end{array}$ & Quota \\
\hline Complicated Goals & $170,36(91 \%)$ & $145,92(75 \%)$ \\
\hline Easy Goals & $151,93(87 \%)$ & $139,73(73 \%)$ \\
\hline High Performance & Spesific Target & Non-SpecificTarget \\
\hline
\end{tabular}

Source : Attachment 3

Table 5 above shows that more than $70 \%$ of the participants believed that the intention to do the coding task was to obtain vouchers. For the record, the number of coupons determines the types of prizes accepted. The more vouchers, the more rewards with a more excellent value. Reinforcement theory can explain this finding, that the positive consequences of a high number of accurate coding will provide a higher return. This positive consequence will drive positive behavior to achieve high performance. Participants behave to do coding correctly as much as possible because there are positive consequences of this behavior. This can be seen from the increasing understanding of proper coding in the second coding session.

Participants' preferences for the two attributes of goal setting theory as described in the second hypothesis testing are supported by the average participant performance achievements in table 5, namely:

a. Participants with challenging goals and get different specificity treatment, then participants who get specific goals will have more significant performance achievements $(170,36)$ than participants with non-specific goals $(145,92)$

b. Participants with manageable goals and receiving different specificity treatment, participants with specific goals have more significant performance achievement (151.93) than participants who have nonspecific plans $(139,73)$.

c. In specific goal conditions, participants who received brutal goal treatment had out the coding task in each cell can be seen in Table 5 below: more significant performance achievement $(170,36)$ than participants with easy goals $(151,93)$

d. In conditions of non-specific goals, participants with challenging goals have more significant performance achievement (145.92) than participants with easy plans (139.73)

These findings confirm goal-setting theory, which explains that specific and challenging goals will shape individual motivation. Particular goals provide clear information to individuals about the targets that must be achieved to make good plans to achieve these goals. A problematic goal becomes a challenge for individuals to use all the resources they have to achieve goals. Challenges to achieving goals become drivers of individual behavior. The highest performance achievement by participants with specific and challenging goals provides evidence that goal setting theory can explain individual behavior in achieving goals with a cognitive approach.

The comparison of goal specificity and goal difficulty attributes in the table above shows support for hypothesis 2 descriptively. This can be seen in participants' performance achievements with specific and non-specific treatment, with easy and difficult difficulty level treatments, so the performance achievements with specific goals have higher performance outcomes (170.36 and 151.93) compared to non-specific performance achievements (145.92 and 139, 
73). Conversely, suppose the findings are classified based on the level of difficulty of the objectives. In that case, the variation in target achievement magnitude is not the same as the classification of specific purposes. This shows that not always challenging goals have a higher performance than easy plans. Participants with easy but particular goals have higher performance outcomes (151.93) than those with challenging and non-specific goals (145.92). These findings support the statement in hypothesis 2 that goal specificity is a factor that participants pay more attention to in achieving goals. This theory's cognitive approach implies that clarity of goals to be completed will encourage individuals to plan, strategize, and use their resources properly.

In terms of reinforcement theory, the percentage of participants who believed that the intention to achieve goals is an incentive to be received was more significant for participants with specific conditions than participants with non-specific conditions. It can be understood that goal attainment behavior can be explained by goal-setting theory through the role of antecedents of goal specificity and goal difficulty with a cognitive approach. Meanwhile, reinforcement theory can explain that motivation to achieve goals can be formed from an incentive system received by participants as a consequence of achieving goals. Goal specificity has a vital role in motivating individuals to achieve goals, both from the point of view of goal setting theory and reinforcement theory.

\section{CONCLUSIONS}

This study found that individual motivation to achieve predetermined goals is determined by setting goals that have specific and intricate characteristics. The role of information about clear goals and provide challenges for individuals will encourage individual cognitive processes to carry out activities that promote goals. This study's findings also suggest that there is a personal preference for the specific characteristics of plans compared to the attributes of goal difficulty.

From the consequent side, this study's findings support the reinforcement theory, which states that individuals will consider the positive consequences of the incentive system when goals are achieved. When the incentive system that will be received provides a positive experience, the individual will repeat the same behavior. The incentive system can explain the formation of motivation to achieve goals by defining the reinforcement theory.

Further research that can improve this study's findings includes (1) this study has not used the intensity attribute to explain individual behavior. The incentive system in research is more discussed in terms of reinforcement theory, not in terms of the intensity attribute of the goal-setting approach, (2) findings regarding the opinions of participants that the intention to do coding tasks is a reward, which can be further researched from the ethical aspect of the possibility of doing work to achieve Maximum performance without considering ethical factors and (3) experimental design that uses two assignment sessions to apply reinforcement theory has limitations because it does not test whether there is a learning effect in the assignment.

\section{REFERENCES}

Arsanti, Tutuk A. 2009."Hubungan Antara Penetapan Tujuan, Self Efficacy dan Kinerja", Jurnal Bisnis dan Ekonomi (JBE): hal. 97-110.

Cheng, J., Caroline Lo, dan Jure, L., (2017), Predicting Intent Using Activity Logs: How Goal Specificity and Temporal Range Affect User Behavior, Proceeding in International World Wide Web Conference Committee (IW3C2), April 3-7, 2017, Perth, Australia.

Early, P. Christopher., Lee, Cynthia., dan Hanson, L. Alice. (1990). Joint Moderating Effects of Job Experience and Task Component Complexity: 
Relation Among Goal Setting, Task Strategies, and Performance. Journal of Organizational Behavior. Vol. 11, No. 1, 3-15.

Gollwitzer, P. M., Heckhausen, H., \& Steller, B. (1990). Deliberative and implemental mind-sets: Cognitive tuning toward congruous thoughts and information. Journal of Personality and Social Psychology, 59(6), $\quad 1119$ 1127. https:// doi.org/10.1037/0022 $-3514.59 .6 .1119$

Jong, J dan Sue F, (2020), The Role of Goal Specificity in Relationship between Leadership and Empowerment, Public Personal Management, vol 1, https:// doi.org/10.1177/009102602 $\underline{0982330}$

Klein, Howard.J., Ellen, M Whitner., dan Daniel, R Ilgen, (1990), The Role of Goal Specificity in The Goal-Setting Process, Motivation and Emotion, Vol. 14 No.9, page 179-193.

Kleingled, Ad., Heleen, V.M. dan Lidia, A., (2011), The Effect of Goal Setting on Grup Performance: A-Meta Analysis, Journal of Applied Psychology, Vo. 96 No. 6, page 12891304.

Latham, G.P, dan Locke, E.A, (1991), Selfregulation through Goal Setting, Organizational Behavior and Human Decision Processes, Vo. 50, page 212247

Latham, Gary P, dan Yulk, Gary A (1975), A Review of Research on the Application of Goal Setting in Organizations, Academy of Management Journal, Vol. 18, No. 4, 824-845

Locke, E. A, (1996), Motivation through Conscious Goal Setting, Applied and Preventive Psycology, Vol. 5, page 117124.

Locke, E. A. (1968). Toward a Theory of Task Motivation and Incentives. Organizational Behavior and
Human Performance, Vol. 3, 157189.

Locke, E.A dan Latham, G.P, (2004), What should We Do about Motivation Theory? Six Recommendations for the twenty-first Century, Academy of Management Theory, Vol 29 No.3, page 389-403.

Locke, E.A, Thomas, L, dan Latham, G.P, (1989), Goal Setting Theory and Job Performance, In L. A. Pervin (Ed.), Goal concepts in personality and social psychology (p. 291-326). Lawrence Erlbaum Associates, Inc. https://psycnet.apa.org/record/19 89-97460-008

Murniati, MP, Ranto S dan Clara S, (2016), Efek pengukuran Keuangan dan Non Keuangan terhadap Kinerja: Pandangan Teori Penetapan Tujuan, Jurnal Organisasi dan Management, Vol. 12 No.1, page 13-25.

Newstrom, J.W. dan K. Davis, (1993), Organizational Behavior: Human Behavior at Work (Edisi Kesembilan). New York, NY: McGraw-Hill, Inc..

Swezey, R.W., Meltzer, A.L, dan Salas, E., (2004), Some Issues Involved in Motivating Teams, NJ: Lawrence Erlbaum Associate, ISBN 9780805812879, page 146

Wallace, S. G., \& Etkin, J. (2017). How Goal Specificity Shapes Motivation: A Reference Points Perspective. Journal of Consumer Research, 44(5), 10331051. doi:10.1093/jcr/ucx082

\section{ATTACHMENT}

Appendix 1: Experimental procedure

In this experiment, the manipulated variables were an incentive system based on a quota scheme and the difficulty of targets and clarity of targets for participants' perceptions. The assignment in this experiment is to change the numeric code in the form of letters. The following are several stages of the experiments carried out in this study: 


\section{$\underline{\text { Pre-Experiment }}$}

The experimenter first conducted a pre-experimental experiment to determine how much assignment was deemed problematic for the subject and how many work levels were considered manageable. By taking ten samples to do pre-experiment. The target average achieved from this preexperimental sample is 100 number coding numbers that can be sampled correctly. From the value of 100 , it is determined the difficult target level is to add the quota of 15 codes simultaneously. If the number of correct coding made by the participant can exceed the target assignment set, the participant will get an additional bonus coupon with the following calculation:

\section{Experiment}

1. Goal difficulty is determined based on preexperiment. Challenging goals are the setting of targets for performance above average (115 codings correctly), while easy plans are setting targets for work above average (90 codings correctly)

2. The intermediate experimenter's information determines goal specificity, the treatment for specificity after the 1st coding session. Treatment/commitment for specific purposes provides information regarding the increase in the target in session 2, which is 120 . Simultaneously, the goal is not straightforward. Only knowledge is given about the increase in the coding target.

3. The experimenter informs the subject that an incentive will be given if the matter can achieve the correct targeted number of assignments. Every five workings of the valid code, the case will be rewarded as much as one coupon, where the subject will receive this coupon if the issue has been able to reach the specified coding target.
Topics will get an additional incentive of 2 lottery coupons for every five workings of the correct code that can be made above the target goal set.

\section{Manipulation Checks}

This test is carried out to ensure that researchers' manipulation of the incentivegiving scheme and the conditions for setting targets have been successfully carried out. The researcher explained the requirements of the incentive scheme and the assignment model for each subject before starting the assignment.

a. Check the Manipulation of the Quota Incentive Scheme

The quota incentive scheme manipulation to participants is carried out by providing information about the incentive scheme given to participants. If the participants do not understand, the participants can ask the experimenter until the participants understand the incentive system that has been established. Participants will receive a fixed-wage incentive with the quota incentive system if participants can achieve the assignment target. Participants will still be rewarded for each unit of output that participants can produce above the assignment target. Participants will get a bonus of 2 coupons for each company of production made above the mark. Information on this incentive scheme is given before the participants start the assignment session (Working). If the number of coding is correct $=$ the target quota amount set, a coupon will be obtained with the following calculations:

Fixed Incentive Amount $=$ Target Assigment

If the number of correct coding by the participant exceeds the specified assignment target, the participant will get an additional bonus coupon with the following calculations :

Number of coupons earned

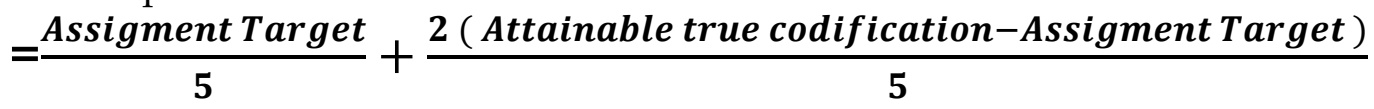


Table 3.2 .Check The Manipulation of the Quota Incentive Scheme

\begin{tabular}{|c|c|}
\hline Number of Correct Coding & Number of Coupons Earned \\
\hline 50 & $\ldots \ldots \ldots \ldots \ldots$ \\
\hline 70 & $\ldots \ldots \ldots \ldots \ldots$ \\
\hline 110 & $\ldots \ldots \ldots \ldots \ldots$ \\
\hline
\end{tabular}

b. Manipulation Checks Target Difficulty

Conditions and Target Specifications

1. Were the target setting conditions set

by Yoel difficult to achieve for you?

$$
\text { O Yes O No }
$$

Tests of Between-Subjects Effects

Appendix 2: Homogeneity Test

Performance differences by gender

Was the target for the next assignment clearly stated by Yoel ?
O No

Dependent Variable:WA1234

\begin{tabular}{|l|r|r|r|r|r|}
\hline Source & $\begin{array}{c}\text { Type III Sum } \\
\text { of Squares }\end{array}$ & Df & \multicolumn{1}{c|}{$\begin{array}{c}\text { Mean } \\
\text { Square }\end{array}$} & \multicolumn{1}{c|}{ F } & \multicolumn{1}{|c|}{ Sig. } \\
\hline Corrected Model & $1487,038^{\mathrm{a}}$ & 1 & 1487,038 & 1,302 &, 260 \\
Intercept & 1120728,998 & 1 & 1120728,998 & 981,247 &, 000 \\
JK & 1487,038 & 1 & 1487,038 & 1,302 &, 260 \\
Error & 53680,962 & 47 & 1142,148 & & \\
Total & 1185137,000 & 49 & & & \\
Corrected Total & 55168,000 & 48 & & & \\
\hline
\end{tabular}

a. R Squared $=, 027$ (Adjusted R Squared $=, 006$ )

Performance differences by age

Tests of Between-Subjects Effects

Dependent Variable:WA1234

\begin{tabular}{|l|l|l|l|l|l|}
\hline Source & $\begin{array}{l}\text { Type III Sum } \\
\text { of Squares }\end{array}$ & df & $\begin{array}{l}\text { Mean } \\
\text { Square }\end{array}$ & F & Sig. \\
\hline Corrected Model & $11791,185^{a}$ & 9 & 1310,132 & 1,178 &, 336 \\
Intercept & 622274,479 & 1 & 622274,479 & 559,486 &, 000 \\
Umur & 11791,185 & 9 & 1310,132 & 1,178 &, 336 \\
Error & 43376,815 & 39 & 1112,226 & & \\
Total & 1185137,000 & 49 & & & \\
Corrected Total & 55168,000 & 48 & & & \\
\hline
\end{tabular}

a. $\mathrm{R}$ Squared $=, 214$ (Adjusted R Squared $=, 032$ )

Performance differences by origin of study program 
Tests of Between-Subjects Effects

Dependent Variable:WA1234

\begin{tabular}{|c|c|c|c|c|c|}
\hline Source & $\begin{array}{c}\text { Type III Sum } \\
\text { of Squares }\end{array}$ & $\mathrm{df}$ & $\begin{array}{l}\text { Mean } \\
\text { Square }\end{array}$ & $\mathrm{F}$ & Sig. \\
\hline Corrected Model & $228,167 \mathrm{a}$ & 1 & 228,167 & 195 & 661 \\
\hline Intercept & 569624,085 & 1 & 569624,085 & 487,303 & 000 \\
\hline Progdi & 228,167 & 1 & 228,167 & 195 & 661 \\
\hline Error & 54939,833 & 47 & 1168,933 & & \\
\hline Total & 1185137,000 & 49 & & & \\
\hline Corrected Total & 55168,000 & 48 & & & \\
\hline
\end{tabular}

a. R Squared $=, 004$ (Adjusted R Squared $=-, 017$ )

Appendix 3: Hypothesis Test 
Independent Samples Test

\begin{tabular}{|c|c|c|c|c|c|c|c|c|c|}
\hline & \multicolumn{2}{|c|}{$\begin{array}{c}\text { Levene's Test } \\
\text { for Equality of } \\
\text { Variances }\end{array}$} & \multicolumn{7}{|c|}{ t-test for Equality of Means } \\
\hline & \multirow[b]{2}{*}{$F$} & \multirow[b]{2}{*}{ Sig. } & \multirow[b]{2}{*}{$\mathrm{t}$} & \multirow[b]{2}{*}{$\mathrm{df}$} & \multirow[b]{2}{*}{$\begin{array}{l}\text { Sig. (2- } \\
\text { tailed) }\end{array}$} & \multirow[b]{2}{*}{$\begin{array}{c}\text { Mean } \\
\text { Difference }\end{array}$} & \multirow{2}{*}{$\begin{array}{l}\text { Std. Error } \\
\text { Differenc } \\
\mathrm{e}\end{array}$} & \multicolumn{2}{|c|}{$\begin{array}{c}95 \% \\
\text { Confidence } \\
\text { Interval of the } \\
\text { Difference }\end{array}$} \\
\hline & & & & & & & & $\begin{array}{c}\text { Lowe } \\
\mathrm{r}\end{array}$ & $\begin{array}{c}\text { Uppe } \\
\text { r }\end{array}$ \\
\hline $\begin{aligned} \text { H1 } & \text { Equal } \\
& \text { variance } \\
& \text { s } \\
& \text { assumed }\end{aligned}$ & 2,301 & ,145 & $-2,215$ & 20 & , 039 & $-30,636$ & 13,832 & 59,490 & $-1,783$ \\
\hline $\begin{array}{l}\text { Equal } \\
\text { variance } \\
\text { s not } \\
\text { assumed }\end{array}$ & & & $-2,215$ & $\begin{array}{r}16,45 \\
4\end{array}$ & ,041 & $-30,636$ & 13,832 & 59,894 & $-1,379$ \\
\hline
\end{tabular}

Independent Samples Test

\begin{tabular}{|c|c|c|c|c|c|c|c|c|c|}
\hline & \multicolumn{2}{|c|}{$\begin{array}{l}\text { Levene's } \\
\text { Test for } \\
\text { Equality } \\
\text { of } \\
\text { Variances }\end{array}$} & \multicolumn{7}{|c|}{ t-test for Equality of Means } \\
\hline & \multirow[b]{2}{*}{$\mathrm{F}$} & \multirow[b]{2}{*}{ Sig. } & \multirow[b]{2}{*}{$\mathrm{t}$} & \multirow[b]{2}{*}{$\mathrm{df}$} & \multirow[b]{2}{*}{$\begin{array}{l}\text { Sig. (2- } \\
\text { tailed) }\end{array}$} & \multirow{2}{*}{$\begin{array}{c}\text { Mean } \\
\text { Differenc } \\
\mathrm{e}\end{array}$} & \multirow{2}{*}{$\begin{array}{c}\text { Std. Error } \\
\text { Differenc } \\
\text { e }\end{array}$} & \multicolumn{2}{|c|}{$\begin{array}{l}\text { 95\% Confidence } \\
\text { Interval of the } \\
\text { Difference }\end{array}$} \\
\hline & & & & & & & & Lower & $\begin{array}{c}\text { Uppe } \\
\mathrm{r}\end{array}$ \\
\hline $\begin{array}{l}\text { H2 Equal } \\
\text { variance } \\
\text { s } \\
\text { assumed }\end{array}$ & $\begin{array}{r}1,69 \\
7\end{array}$ & $\begin{array}{r}20 \\
4\end{array}$ & $\begin{array}{r}-, 46 \\
2\end{array}$ & 25 & 648 & $-6,017$ & 13,033 & $-32,860$ & 20,826 \\
\hline $\begin{array}{l}\text { Equal } \\
\text { variance } \\
\text { s not } \\
\text { assumed }\end{array}$ & & & $\begin{array}{r}-, 44 \\
5\end{array}$ & $\begin{array}{r}19,29 \\
0\end{array}$ & 662 & $-6,017$ & 13,532 & $-34,310$ & 22,277 \\
\hline
\end{tabular}

